\title{
CHAEREAS, HIPPOLYTUS, THESEUS: TRAGIC ECHOES, TRAGIC POTENTIAL IN CHARITON
}

\author{
J. H. D. Scourfield
}

\begin{abstract}
$\mathrm{T}_{\mathrm{h}}$ he affinities of Chariton's romantic fiction Chacreas and Callirboe with the ancient theatre have often been remarked. Two important scenes-the plot in the first book where one of the unsuccessful and aggrieved suitors of the beautiful Callirhoe schemes to dupe her husband Chaereas into believing that she has a lover, and the moment of high emotion in the law-court at Babylon, where Chaereas, whom Callirhoe had believed dead, suddenly appears to her, her new husband Dionysius, and the whole gathering, to general astonishmentare presented in explicitly theatrical terms. ${ }^{2}$ At the same time, the history of criticism on this text has sought to emphasize its dramatic character. A century ago Richard Reitzenstein, building on associations between narrative and drama found in ancient rhetorical theory and elsewhere, offered an analysis of the work dividing it into five sections; the conception thus formed of Cbaereas and Callirboe as a kind of drama in five acts-a highly subjective way of looking at the textwas seized on by later scholars and developed further. ${ }^{3}$ Reacting to this, but nonetheless thinking in the same kind of orbit, Bryan Reardon suggestively saw the work as structured around a series of agones between Chacreas and his several
\end{abstract}

This article has its roots in a series of papers given some years ago in different fora, beginning with the Colloguium on Aspects of Anger in Antiquity held at the University of Heidelberg in September 1999; thanks are due to Susinna Braund and Glenn Most for inviting me to take part in that cvent, and to all the participants for their contributions to the discussion. Later versions were presented at the Dublin Classics Seminar in October 1999, and at the Third International Conference on the Ancient Novel (ICAN 2000) held in Groningen in July 2000; the constructive observations of Catherine Connors and Sandra Schwartz on the latter occasion were especially helpful. I am also grateful to Douglas Cairns and lohn R. Morgan for valuable comments on a near-final draft of the developed article; the anonymous referees for various good suggestions; and especially Monica Gale, who discussed with me many individual points and helped to shape my thinking on intertextuality.

${ }^{1} I$ retain what might be called the received title, against the recent tendency to prefer the shorter Callirbo; the case for the latter as more accurately reflecting the original title is strong, but the issue is not as simple or settled as is often supposed. For argument in favour of Callirhoe see, for example, Plepelits 1976: 28-29, Reardon 1996: 315-316; for full discussion of the (problematic) evidence conceming the titles of all the Greek novels, with generic implications, see Whitmarsh 2005. Tilg 2010, an important book which interestingly proposes the title Narratives about Callirbo' (sce esp. 214-217), appeared too latte for me to be able to take full account of it in this article.

${ }^{2}$ See Chareras and Calliwo (CGC) 1.4.1-3, 8-9; 5.8.2; also, for example, 4.4.2, 6.3.6.

${ }^{3}$ Reitzenstein 1906: 95-96 (with background from 84), followed notably by Perry (1967: 141-142), and Schmeling (1974, esp. 49, 80-81); the perceived dramatic character of the work is particularly prominent in S.hmeling's analysis. For criticism of Reitzenstein and Perry, see esp. Müller 1976: $118-121$ 
rivals. ${ }^{4}$ Again, the high proportion of direct speech in the text has seemed to some a dramatic feature-though this could equally (or better) be associated with its epic quality, or even its affinities with historiography.

More valuable for interpretation have been those approaches which have sought to establish firm and clear connections with dramatic genres. New Comedy in particular has been seen as one of the formative influences on Chaereas and Callirboe and indeed the Greek novel generally. ' Euripidean "melodrama" or "tragicomedy" is frequently invoked similarly, but this apart, tragedy has tended to be regarded as a genre of relatively minor significance in the multiplicity of generic models lying behind the novel. ${ }^{8}$ This is not altogether surprising: as a whole, and with regard especially to the way in which they conclude- the "happy end"-the extant Greek novels are far from tragic as the Agamemnon or the Antigone or the Bacthae are tragic, and, as far as Chariton's novel is concerned, it is hard to argue with the judgement of Massimo Fusillo that it has a "strong consolatory character"-which, for Fusillo, means "on the thematic level, an absence of tragic conflicts, of problematic ambiguities and ideological depths, and a concentration on private values and erotic passions, destined to an optimistic triumph." It may be, however, that this essential rejection of tragic influence in favour of the much more apparent influence of comedy has resulted in the eliding of, or the straightforward failure to notice, intertextual relations between passages in the Greek novels and tragedy of the "tragic" type. ${ }^{10}$ In this article I argue for the presence of a tragic intertext in two scenes in Chaereas and Callirboe, one

\footnotetext{
${ }^{4}$ Reardon 1982: 8-11 (= Swain 1999: 169-172).

${ }^{5} \mathrm{Hägg}$ (1971: 91) reckons the proportion of direct speech in CEC at 44 per cent; for this as a
} dramatic feature, see, for example, Goold 1995: 13; Holzberg 2001: 66. For the epic character of the work, see esp. Müller 1976: 126-136; Hirschberger 2001; Scourfield 2003: 166-168, 172-175; and for its connections with historiography, esp. Bartsch 1934 (20-25 on speeches); Papanikolaou 1973: 16-22; J. R. Morgan 1993: 205-208; Hunter 1994; Smith 2007: 153-163, 172-192.

'See notably Corbato 1968; Borgogno 1971; Fusillo 1989: 43-55; Mason 2002; interesting observations are also made by Lowe (2000: 223-226).

${ }^{7}$ The play most commonly cited in this connection is Euripides' Helen. See, for example, (for the Grcek novel in general) Fusillo 1989: 33-34; Reardon 1991: 130-132; (for CSC in particular) Marini 1993; Hirschberger 2001: 166-167, 175-176.

${ }^{8}$ See, however, Billault 1998 for a useful survey of points of contact between tragedy and the novcl.

"Fusillo 1997: 215.

${ }^{10}$ For a recent exception, see Liapis 2006, on a passage in Achilles Tatius. In CESC, a few conncetions only have been observed. Traces of Euripides' Medea may be seen in Callirhoc's reference to Medea at 2.9.3-4: see Kaimio (1996: 56), who also notes a situational parallel with the Hippolytus, for which see below, 305, n. 65; Hirschberger 2001: 178 (though over-reading on the basis of an unlikely and unacknowledged conjecture; a possible further allusion to the play is identifed at 179); Scourficld 2003: 178 with n. 68; Smith 2007: 111-116. Echoes of Soph. Aj. 550-553 have been detected at 2.9.4, 3.8.8, and 5.10.3: see Papanikolaou 1973: 16; Gerschmann 1974: 57; Hirschberger 2001: 179 (who also [180], less persuasively, perceives a reminiscence of $A j .567-570$ at 8.4.6); Smith 2007: 117-119. Finally, as Gcrschmann (1974: 133, n. 23) notes, D'Orville (1750: 64 [Annotationes]) links Chacreas' pleading for his own execution at 1.5.4-5 with Oedipus' words at Soph. OT 1410-12; 
of them of central importance to the action of the novel; and then consider the consequences of this identification for our reading and appreciation of this work.

A few initial words of clarification on my position in regard to the discourse of "intertextuality" and on the language I incline to use in expressing intertextual relations may be helpful. My argument will be that Chariton's novel can be shown to be in significant relationship with a fifth-century tragic drama. The existence of this relationship is demonstrable through a complex of verbal, situational, and other connections. My preferred metaphor for referring to this and other, similar, relationships is to say that the later text "echoes" the earlier, though I will sometimes use the expression "allude to," or, effectively looking at the relationship from the opposite pole, say that the earlier text leaves "traces" in the later. My use of one term rather than another at any particular point does not imply an essentially different understanding of the nature of the relationship between the texts concerned, or an unstable attitude towards the question of authorial intention. The problematics of "intention" are well known, and my commitment is to what Stephen Hinds has called "a text-and-reader-oriented intertextuality"; at the same time, Hinds has valuably shown how the language of "allusion" may retain a practical value within a broader "intertextual" discourse, ${ }^{11}$ and I have not sought to eliminate the notion of the alluding (real or implied) author from my discussion entirely-in places, indeed, Chariton's text may suggest an "intention" quite strongly. ${ }^{12}$ Nonetheless, my approach is fundamentally reader-based; I take the view that whatever the author may or may not have "intended," the intertext for whose presence I argue is in principle identifiable by any reader, modern or ancient.

The key scene occurs at the end of the sequence of events that stem from the desire of Callirhoe's defeated suitors for revenge on Chaereas. The plot mentioned above results in Chaereas' being persuaded that Callirhoe is unfaithful to him. Pretending to go to the country, he keeps watch on his house after dark; and on seeing a man, dressed in the fine clothes of a lover, enter the house-admitted, in reality, by Callirhoe's maidservant, whom he has seduced as part of the plot ${ }^{13}$ - Chaereas assumes that what he has been told about his wife is true, and loses control:

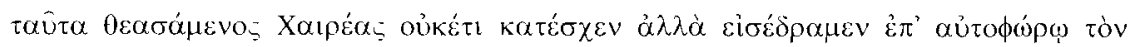

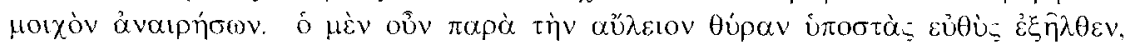

the inclusion in both petitions of a request to be thrown into the sea and Chaereas' reference to his having committed an act worse than parricide offer good grounds for supposing a direct ceho.

${ }^{11}$ Hinds 1998 , esp. 17-51; quotation at 49. My understanding of and approach to intertextuality owe most to work done in the field of Latin literature, especially poetry; in addition to Hinds, see particularly Fowler 1997.

${ }^{12}$ For example, the programmatic quality of the passage at 1.1 .3 where Chaereas is first introduced (sce below, 296-297) suggest design in the text.

${ }^{13}$ The maid and the seducer can both be regarded as New Comedic character types, and the scene at this point as having a strong comic flavour; cf. Mason 1998: 2 and 2002: 21-22. 


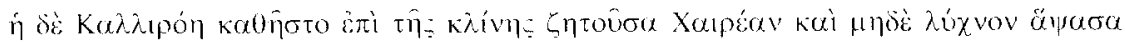

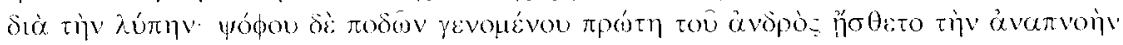

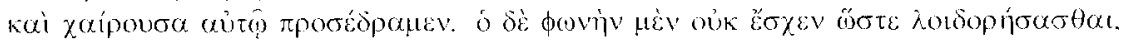

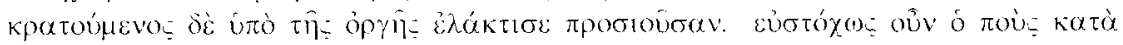

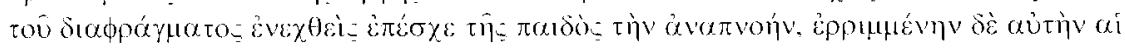

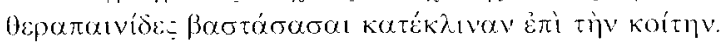

Seeing this, Chacreas could no longer restrain himself but rushed in to kill the adulterer in the act. He, however, had hidden by the courtyard door, and made his exit immediately. But Callirhoe was sitting on her couch longing for Chacreas, and was so unhappy that she had not even lighted a lamp. There was the sound of footsteps; she was the first to recognize her husband by his breathing, and joyfully ran to mect him. But he could find no voice to revile her with, and, overcome by anger, kicked at her as she ran towards him. His foot struck her right in the diaphragm and stopped the girl's breathing. She collapsed, and her maidservants picked her up and laid her on the bed. $(1.4 .10-12)^{14}$

This is the critical moment in the setting-up of the plot of the novel: the separation of the lovers, which is both the engine of the story and, in a sense, what it is about, depends on Callirhoe's apparent death ${ }^{15}$ and burial, and her subsequent rescue from the tomb by robbers who carry her off from Syracuse (where the initial events have occurred) to Milctus. The situation is that of the classic love triangle, or rather, suspected triangle: a husband believes that his wife is engaging in an adulterous relationship, and, enraged, attacks her. Nearly forty years ago Borgogno suggested that this scene owed a debt to the Perikeiromene of Menander. ${ }^{16}$ This play of course survives incomplete, but it is clear that the situation from which the action derives is roughly as follows. Glycera, mistress of the soldier Polemon, is seen by his slave, Sosias, in an embrace with her neighbour, Moschion. Sosias reports the incident to Polemon, who has just returned from military campaigning. Moschion is in fact Glycera's brother, but this is known to no one but Glycera herself, and, put into a jealous rage by the news Sosias brings him, Polemon assaults Glycera and cuts off her hair. Though none of this was necessarily represented on stage, ${ }^{17}$ in essentials the situation is very like that in Chariton: we have an apparent love triangle, misleading information, and a consequent assault critical in the development of the plot. While there is little more concrete evidence to underpin the identification of this episode as a model for Chariton, ${ }^{18}$ I have no wish to dispute it: the "openness" of the Greek novel as a

${ }^{14}$ I follow the text of Reardon 2004; translations are my own, though debts to those of Reardon, in Reardon 1989: 17-124, and Goold 1995, will be apparent in places.

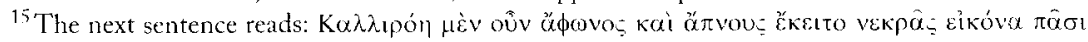

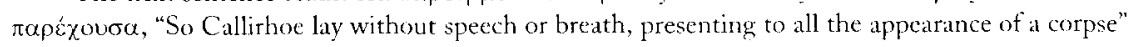
(1.5.1).

${ }^{16}$ Borgogno 1971: 257-258; see also Laplace 1980: 111; Hunter 1994: 1064. In referring below to specific passages of the play I follow the line-numbering of Arnott 1996.

${ }^{17}$ See Arnott 1996: 375-376.

${ }^{18}$ There are, of course, explicit references to Polemon's anger, jealousy, and abusive behaviour (Men. Pk. 163,723,987-988), and, if the lacuna at 723 is correctly filled by Sudhaus (ikourovo; sce 
literary form has become part of critical orthodoxy, and it is entirely appropriate to see Chaereas and Callirboe as a palimpsestic text, displaying numerous overlapping debts. ${ }^{19}$ My contention, however, is that a closer and more significant connection can be observed with a scene in tragedy, with important implications.

In Euripides' Hippolytus, when Theseus returns from Delphi to find Phaedra dead, and reads the wax tablet on which she has accused Hippolytus of raping her, he immediately curses his son:

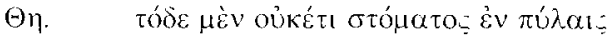

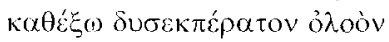

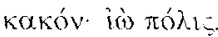

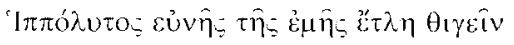

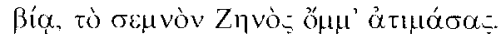

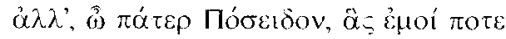

$$
\begin{aligned}
& \dot{\alpha} \rho \dot{\alpha}=\hat{v} \pi \dot{\varepsilon} \sigma \chi \sigma \mathrm{v} \tau \rho \varepsilon \hat{\zeta}, \mu 1 \alpha \hat{\alpha} \kappa \alpha \tau \dot{\varepsilon} \rho \gamma \alpha \sigma \alpha 1
\end{aligned}
$$

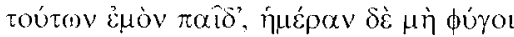

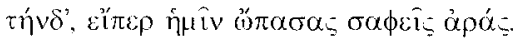

Th. No longer shall I hold within the gates of my mouth this ruinous evil, whose utterance brings me pain. Citizens! Hippolytus has dared to lay hands on my marriage-bed by force, dishonouring the holy eye of Zeus! But, father Poseidon, those three curses which you once promised mc - with one of these destroy my son, and may he not get beyond this day, if indeed the curses you granted me are sure. $(882-890)^{211}$

The chorus of women of Troezen instantly urge Theseus to withdraw the curse (891-892), and at Hippolytus' entry moments later they press him to "relax [his]

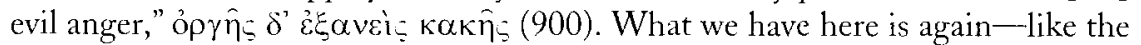
assault episode in the Perikeiromene-closely parallel to the situation in Chariton: a rash act committed in anger by a husband on the basis of false information about transgressive sexual behaviour involving his wife. The obvious differences in the Euripidean situation, such as the family relationships between the three principals, the abnormal desires of Hippolytus and Phaedra, Phaedra's role in providing the false information, and the fact that she is dead, should not obscure the common

\footnotetext{
Borgogno 1971: 258; Amott 1996: 438), a close parallel to Hermocrates' exculpation of his son-in-law Chacreas (sec below, 299).

${ }^{14}$ On the generic complexity of the Greek novel-its "polyphony"--see esp. Fusillo 1989: 17-109. In the episode of the suitors' plot and Chaereas" assault on Callirhoe the influence of a further text has been detected, namely Lysias 1; for this see recently Kapparis 2000 (who is unaware of having been anticipated by Hammer 1922: 106-107), with the critique of Porter 2003, esp. 433-434, 438-440; Smith 2007: 120-123. For present purposes it suffices to say that, while it is possible that Chariton "borrowed a number of elements" from the lysias speech (Kapparis 2000: 382; contra, Trenkner 1958: 159), important features to which I draw attention below are lacking; in particular, the assailant does not act hastily or under the impulse of uncontrolled anger, the information on which he acts is not falsc, and the critical action - the killing of the adulterer-is by no means akousion (see below, 298-299).

${ }^{20}$ Except where otherwise indicated, the Hippolyns is cited aceording to the text of Diggle 1984 (with iot: subscript for adscript); translations are mine.
} 
pattern which is evident: the vital elements are the anger, its causes, and its consequences. I have written of the importance of anger in Chaereas and Callirboe elsewhere, stressing its epic associations; ${ }^{21}$ but it is a characteristic motif of tragedy too, ${ }^{22}$ and in the present case the filter offered by the Hippolytus changes the complexion of Chariton's text. To pursue for a moment the situational parallelism, though Theseus in Euripides' play seems to doubt the efficacy of his curse, the gift of Poseidon, and imposes also a sentence of exile on his son (893-898), the curse will be, must be, terribly fulfilled. Theseus' utterance is a snap action, like a kick, ${ }^{23}$ and it seems that it cannot be revoked; ${ }^{24}$ in any event it is not revoked, and the result is Hippolytus' death. Callirhoe's death, the consequence of Chaereas' kick, is only apparent; but to the characters involved, who conduct her funeral and bury her $\left(C E^{3} C 1.6 .2-5\right)$, it is real enough. In both cases the angry action leads to desperate loss-temporary, and not in the event catastrophic, in the one, but seemingly so at first; and Theseus' desire to die, on finally hearing the truth (1325; cf. 1408, 1410), is matched by Chaereas' longing to kill himself at the equivalent moment ( $C \mathscr{G} C$ 1.5.2).

There are in my view good grounds for regarding the link between the two texts as more than one of analogy; for, in fact, seeing the assault episode in Chariton as a reworking of the situation in Euripides. The trigger is a passage in the first chapter of the novel, which should put the attentive reader in mind of Euripides' play. Having first described the beauty of Callirhoe, the desire for her of high-ranking men from far and wide, and the wish of Eros to make a match of his own choosing, the narrator introduces Chaereas thus:

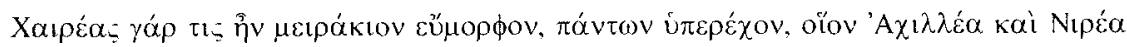

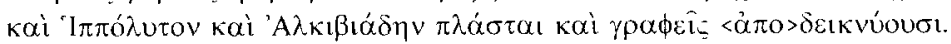

There was a certain Chaereas, a youth who surpassed all in good looks, like Achilles and Nireus and Hippolytus and Alcibiades as represented by sculptors and painters. (1.1.3)

The precise point of comparison-the handsomeness of the characters - is arguably of much less significance at a place in the text where we might expect to find signs of a literary programme than the generic associations which these particular characters bring to the text. ${ }^{25}$ The presence in the comparison of Homeric epic, tragedy, and history is noted by Billault, though he is interested

\footnotetext{
${ }^{21}$ Scourfield 2003, esp. 166-168, 172-175.

${ }^{22}$ The classic tragedy of anger is of course Euripides' Medea; but one might also think (among many examples) of Sophocles' Antigone and Oedipus Tyrannus, Euripides' Heruba, or (for divine rather than human anger) Aeschylus' Fumenides. See generally Harris 2001: 158-165, 168-174, 276-280.

${ }^{23}$ Cf. Artemis' words to Theseus at $1320-24$.

${ }^{24}$ See Barrett 1964: 166 (on Hipp. 43-46).

${ }^{25} \mathrm{In}$ this regard Nireus, a minor figure compared with the rest, and throughout ancient literature little more than a byword for beauty ( $\sec R E 17.1 .708$ ), can be seen as a kind of footnote to the epic Achilles- the best-looking of the Greeks at Troy after Peleus' son (Hom. Il. 2.673-674) takes second place behind him here too. On a more specific level, Smith (2007: 100) observes interestingly how the comparison with Achilles, Hippolytus, and Alcibiades can be construed as problematic: all are
} 
only in its characterizational use and does not pursue the point further. ${ }^{26}$ Hunter too observes the comparison, and points out that Chaereas resembles Hippolytus not only in his beauty but also in the fact that both suffer at the hands of Aphrodite; ${ }^{27}$ but it is the novel's relationship with epic and historiography that he highlights, ${ }^{28}$ and the hint at tragedy in the reference to Hippolytus is hardly taken up. If the mention of Achilles turns our thoughts to epic and to anger, the mention of Hippolytus should direct us to the most famous ancient treatment of this familiar myth. ${ }^{29}$

At this point let me briefly anticipate two possible objections, both of which can be shown to have little substance. The first is that, in the scene of his assault on Callirhoe, Chaereas takes the role not of Hippolytus but of Theseus. I am arguing here, however, for an evocation of Euripides' play in general; and even on a narrower vicw there is no cause to claim inconsistency. In relation to the Homeric intertexts of the novel Chaereas is plainly cast in a variety of roles, including those of both Achilles and Hector; ${ }^{30}$ and there is no reason in the identification of an intertext to demand that correspondences between "source" and "target" texts be exact (indeed, it could be said that exact correspondence is impossible without complete repetition, in the target text, of the source text, and perhaps not even then). Chaereas-as-Theseus may not be what the alert reader expects the prompt at 1.1 .3 to deliver, but $s$ he should not be surprised to be surprised in this way. Nor is it a matter for concern that Chaereas' attack is on the

"famous for their inability to exist on a plane equal with their fellow men." The comparison with Acibiades is explored at great length by $S$ mith in his final chapter (199-248), with further valuable comment on this passage at 214 .

${ }^{26}$ Billault 1996: 126-127; cf., however, Billault 1998: 191, where the comparison with Hippolytus is seen as indicating that Chaereas will experience tragic events, whose severity, when they occur, is underlined by the implicit reference to tragedy.

${ }^{27}$ Hunter 1994: 1079; for Chaereas and Aphrodite see below, 299-300.

${ }^{28}$ Sce esp. 1083-84; history and epic are "the two poles between which his work swings." Alcibiades and Nireus are again mentioned in this connection (1084).

${ }^{29}$ I see no merit in attempting to engage with the idea that Chariton may have known either or both of the other treatments known to have been produced in the fifth-century Athenian theatre, Sophocles' Phaedra and Euripides' Hippolytos Kalyptomenos; endless games an be played with highly fragmentary texts, and from the point of view of the reader what matters is not what text/s Chariton may or may not have had in mind but what text/s are actually evoked in reading $C \& \mathcal{G}$. The surviving Hippolytus-a popular text throughout antiquity, well attested in papyri (see T. Morgan 1998: 115-116, with Table 22 [p. 321])-is, I argue, strongly present in the work.

${ }^{30}$ See, for example, 1.5.2, 4.1.5, 7.4.6 (Achilles); 3.5.6, 7.2.4 (Hector); 7.3.5, 7.4.6 (Diomedes). Callirhoe similarly evokes both Helen and Penelope, most obviously at 5.5.9; see also, e.g., 5.2 .8 (Helen, with Chaereas implicitly-and ironically cast as Paris), 8.1.17 (Penelope, with Chaereas equally marked as Odysseus). Such switching of roles is easily paralleled elsewhere in ancient literature: W. S. Anderson (1957) brilliantly demonstrated how the figure of Turnus in Virgil's Aeneid embodies both Paris and Hector (with the added complication that Turnus sees himself as a combination of Achilles and Menelaus), while Aeneas is mapped on to three Homeric models, Agamemnon, Menelaus, and Achilles (his enemies meanwhile viewing him as Paris); within the genre of the novel, further examples are afforded by Heliodorus' Acthiopica (sec J. R. Morgan 1993: 222-223). 
woman in the triangle rather than the other man: this is essential for Chariton's plot, and it should in any case be observed that Chaereas' first intention is to kill the supposed lover, not Callirhoe (1.4.10). I shall return to the connection with Theseus in a moment; beforc that I want to draw attention to specific features of the assault scene and the trial scene in the next chapter which serve to bind together the parallel actions in the two texts. First, when Chaereas rushes into

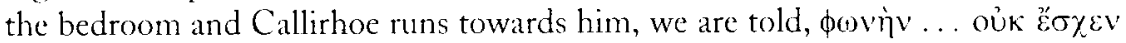

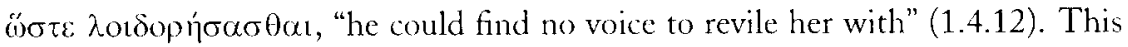
repeats part of an earlier episode, where, in a first attempt to damage the marriage of the lovers, the jcalous suitors fabricate evidence of a revel at Chaereas' house during his absence in the country; this has the desired effect of putting Chaereas into a rage with Callirhoe, and in the confrontation scene which follows (where Callirhoe fiercely rebuts her husband's unjust reproaches, and at the end of which

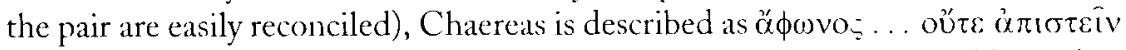

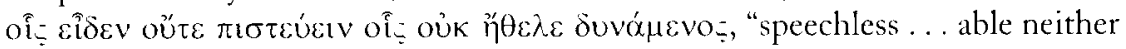
to disbelieve his eyes nor to give credence to what he did not want to believe" (1.3.4). In the present context Chaereas' speechlessness ${ }^{31}$ evokes both the silence of the wax tablet on which Phaedra's accusation against Hippolytus was written ${ }^{32}$ and Theseus' inability to kecp silent, which destroys his son-he speaks rashly, Chaereas, unable to speak, acts rashly, with like results. ${ }^{3.3}$ Still more arresting is Chariton's description of Chaereas' speech in the murder trial which follows, where instead of putting up a defence the young man accuses himself and votes for his own conviction,

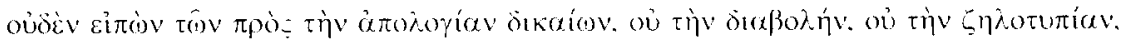
oủ tò ảkoúntov.

putting forward none of the arguments that could justly have been used in his defence-the slander, his jealousy, and the fact that his action was akousion. (1.5.4)

${ }^{31}$ For specthlessness as the consequence of enotion in CEC: sec also $1.1 .1+$ (Callirhoe); 2.5.4, 2.7.4 (Dionysius); 3.9 .2 (priestess of Aphrodite); 4.1.9, 5.5.9 (Nithridates); 6.3.3 (the king); 6.5.10) (the cunuch Artixates); 8.1 .9 (Polvchatmus). It is attributed to Chacreas elscwhere only, I think, at 1.4 .7 , in describing his initial reaction to the report of $C$ allirhoe's infidelity.

32 In both ases, silence bars the way to the truth. An inimimate ubject, the tablet has no voice, and cinnot be questioned; Theseus simply acepts its false message als true. Equally, Chatereas' inability to speak prevents him from getting at the truth by questioning Callirboe. The silenes of the tablet in the Hippolym is emphasized, especially in retrospect, by Thescus" description of it as "crying

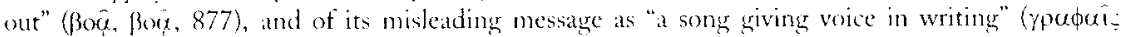

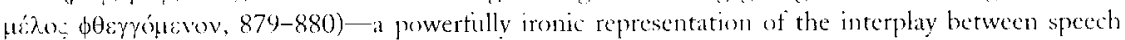
and silence which is such at dominant thene in the tragedy (on which see esp. Knox 1952).

$\therefore$ One might note too the use of the verh katryaly in conjuntion with ouser in both texts: Chatereas, on seeing the alleged lower enter his house, oukit hotioxis" "could no longer restrain himself" (1.4.10); Theseus, having read the writing on the wax tablet, says "no longer shall I hold [oukit . . kutero] within the gates of my mouth this rumous evi], whose utterance brings ane pain" (lipp. 882-884), proceding inmediately to an to the city, declare tippolytus supposed act of rape, and curse his son. 
The key word here is $\alpha$ kouroov, which is repeated shortly afterwards by Chacreas father-in-law Hermocrates in urging his acquittal ("I know that what happened was akousion," 1.5.6), and again in Hermocrates' summarizing of the action of the first part of the novel at 8.7.7, when the whole story is retold from the points of view of Hermocrates and Chatereas ("But the people acquitted you, recognizing that what had happened was akousion"). At the end of Euripides' play Artemis, effecting reconciliation between Theseus and the dying Hippolytus, tells Theseus to embrace his son, "for äkriov you destroyed him" (Hipp. 1433). The meaning of the word ö $\kappa(\omega v$ in this passage has been much discussed; "innocently" is Barrett's approximation, "in ignorance," that is, of the full situation, an attractive alternative. ${ }^{35}$ The latter meaning would be particularly apposite for rkoúriov here: ${ }^{36}$ Chaereas' kick was delivered in utter ignorance of the true circumstances. ${ }^{37}$ But whether Chariton understood it in this way is not germane to the issue; what counts is what I take, given the accumulation of factors, to be a clear pointer to the Hippolytus.

The view I have argued is buttressed by a number of other features in the novel. Most obviously there is the controlling role played by Aphrodite in both texts. ${ }^{38}$ In Euripides the action derives from Aphrodite's determination to punish Hippolytus for rejecting her; Theseus' curse as the instrument of his son's death is already mentioned in the prologue delivered by the goddess herself (Hipp. 44-45). Though Chaereas' kick is not similarly predetermined, it is made clear late in the novel that the goddess is offended by it - here the parallel is with Hippolytus again-and that the sufferings which Chaereas has experienced to this point, which include enslavement, near-crucifixion, and the dangers of war, are her punishment for his assault on Callirhoc, interpreted by Aphrodite as ingratitude and insult. At this point in the text Chaereas, having travelled to the east from Syracuse in pursuit of the kidnapped Callirhoc, has become embroiled in a rebellion in Egypt against the King of Persia, and risen to command of the rebel

${ }^{34}$ Barrett 1964: 413.

${ }^{35}$ See Rickert 1989: 115, who is followed by Halleran (1995: 141, with n. at 266); Rickert's interpretation is grounded in a discussion of Arist. Eith. Nii. 3.1, on which see below, n. 37. MacDowell (1968) prefers "under compulsion."

${ }^{36}$ Reardon (1989: 17-124) and Goold (1995) offer for to a kovorov at 1.5.4 "[the fact] that his action was involuntary" (Reardon) and "the lack of premeditation" (Goold); and for $\alpha$ koúotov at 1.5 .6 and 8.7.7, respectively "unintended" and "involuntary" (Reardon), and "unintended" and "not deliberate" (Goold).

${ }^{37}$ In Aristotle's analysis at Eth. Nic. 3.1, one of the categories of acts that are akousion is that of those done through ignorance ( $\delta i^{\prime} \alpha$ a $\left.\gamma v o t \alpha v\right)$. Cf., on Theseus, Stinton 1975: 248 (= 1990: 177): "Theseus acts wholly $\delta i^{\prime} \not \alpha \gamma v o w$, though his ignorance is culpable to this cxtent, that his $\pi \alpha \theta_{0}-$ (his grief and anger) prevent him from giving due weight to his son's protestations of innocence. So too the curse, which is a natural outcome of his mistake, is culpable because it is hastily uttered and irrevocable." One might say that Chacreas demonstrates a kind of hamartia very like that of Theseus.

${ }^{38}$ Recognition of the intertext in the assault scene may (conversely) suggest less "cosiness" in Chariton's Aphrodite than Reardon 1982: 24 (who observes [23] the parallelism in Aphrodite's role in the two works) would have it. 
fleet; without either of them knowing it, Callirhoe--along with the Persian queen and others left by the king on the Phoenician island of Aradus-is now actually in his possession. Fortune, Tyche, however - one of the external forces at work in the narrative ${ }^{39}$-intends that Chaereas should remain ignorant of this fact and leave Callirhoe behind, alone.

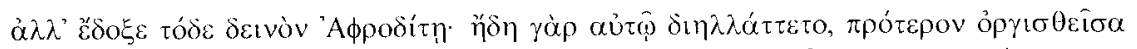

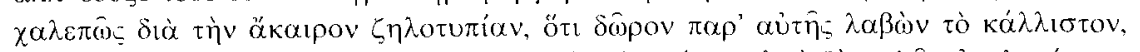

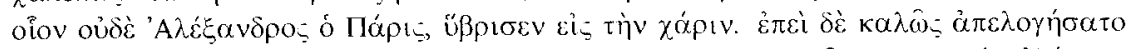

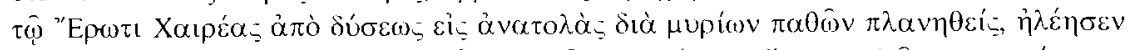

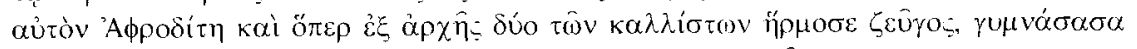

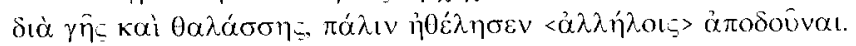

But this seemed too cruel to Aphrodite; by this time she was becoming reconciled to Chaereas, though earlier she had becn made intensely angry by his inappropriate jealousy, because after receiving from her the fairest of gifts, superior even to the gift Alexander Paris had received, he had repaid her kindness with insult. But since Chaereas had now made honourable amends to Love by wandering the world from west to east amid innumerable sufferings, Aphrodite took pity on him, and, having harassed by land and sea the beautiful couple she had originally brought together, she now decided to reunite them. (8.1.3)

Aphrodite's anger against Chaereas is generated by what she regards as the üßpt (cf. úßproqv) involved in his abusing Callirhoe, Aphrodite's gift to him, the most beautiful of women, frequently mistaken for the goddess herself; ${ }^{40}$ Hippolytus' behaviour towards Aphrodite in the Euripidean play is not far removed from this, and we might well see here a reflex of Aphrodite's words at Hippolytus $6, \sigma \phi \alpha \dot{\alpha} \lambda \lambda \omega \delta^{\prime}$

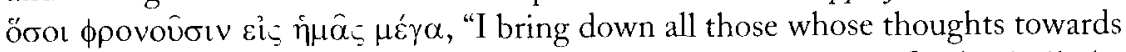

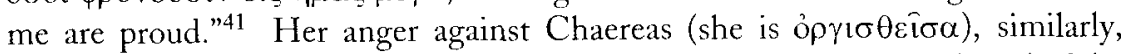
echoes the language of the tragedy: the action of the drama is described by Artemis as the work of Aphrodite, $\pi \lambda$ npoū $\sigma \alpha$ Oupóv, "sating her anger" (1328); ỏ $\gamma \alpha \hat{i}$ is used of her feelings at $1418 .{ }^{42}$

${ }^{39}$ For Tyche in CEC, see esp. Robiano 1984; Van Steen 1998.

${ }^{40} \mathrm{Sec} C \mathrm{CEC}^{2} \mathrm{C} .14 .1,2.3 .5-6,5.9 .1$

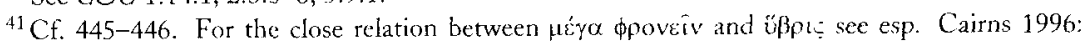
10-17, with consideration of Hipp. 6 at 16. The word $6 \beta p l s$ and its cognates are not themselves used of Hippolytus' attitude to Aphrodite in Euripides' play, but the nurse's assertion to Phaedra that it is $\not \beta \rho \mathrm{l}$ - to want to be superior to the gods (474-475, quoted below, 303) could, mutatis mutandis, readily be applied to Hippolytus too (the point is made independently by Cairns [1997: 73]).

${ }^{42}$ Harris (2001: 300, n. 66) takes opyai here to refer to Theseus' anger. The passage which immediately precedes offers support for this interpretation, but it is hard to read the sentence itself without understanding the anger to be Aphrodite's. In any event Harris's assertion (174, n. 68) that opyr is not used of Aphrodite's anger in this play is erroneous; see Hipp. 438, where the nurse-without knowing of Aphrodite's design to punish Hippolytus, in which Phaedra is merely an instrument, and therefore with irony-tells her mistress, ill and striving to suppress her love for Hippolytus, that the goddess's opy $\alpha$ i has struck her (Nauck's proposal to delete this line is universally ignored by modern editors). The opyoi assumed by the nurse in this passage is generally understood to refer to Aphrodite's punishment-expressed in the form of the illness-for Phaedra's resistance to 
More specific substantiation of the connections between the assault scene and its Euripidean model is afforded by the recurrence at several points of a mythological parallel to the situation of Chaereas and Callirhoe after the assault. ${ }^{43}$ Almost immediately after Chaereas' acquittal in the murder trial preparations are made for Callirhoe's funeral. Lying on a golden bier, wearing her wedding garments, Callirhoe appears so beautiful "that everyone compared her to the sleeping Ariadne" ( $C E^{3} C$ 1.6.2). The allusion is to the abandonment on the shore at Naxos of Ariadne by Theseus; and if the (apparently) dead Callirhoe is like Ariadne, the "murderer" Chaereas must be the counterpart of the hero who abandoned her. A further, more straightforward, comparison between Callirhoe and Ariadne occurs at $4.1 .8 ;^{44}$ but more significant is a passage which appears immediately before the depiction of Aphrodite's anger-with its reference to Chaereas' act of jealousy - in the final book. Fortune was planning that, without realizing it, Chaereas would

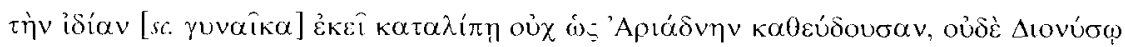

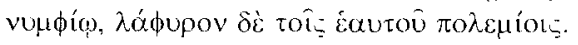

leave his own wife there [on Aradus], not, like Ariadne, asleep, nor for a Dionysus to marry, but as spoils for his enemies. (8.1.2)

Again there is an implicit comparison between Chaereas and Theseus, strengthened this time by a play on the names Dionysus and Dionysius, the god who married Ariadne after her abandonment ${ }^{45}$ and the Greek nobleman who married Callirhoe after her "death," kidnap, and sale in Ionia. Earlier Chaereas himself has, all unwitting, drawn the same parallels; after the discovery of the tomb robbery, he turns to heaven and says:

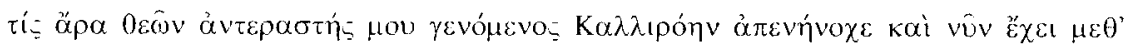

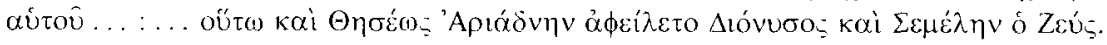

her feelings (so Barrett 1964: 239, Halleran 1995: 188, looking forward to Hipp. 444-446); at another level one wonders whether in the context the word does not carry the overtones of sexual desire to which attention has been drawn particularly by Allen (2000: 54; though see also Harris 2001: 52, n. 11).

${ }^{43}$ The Ariadne/Theseus parallels are also discussed by Smith (2007: 99-104), in the context of an essentially political argument. My identification of the curse scene in the Hippolytus as a model for the assault scene in $C G^{\circ} C$, with its implicit casting of Chaereas as Theseus, incidentally supports Smith's reading of Chaereas as a politically problematic figure for democratic Syracuse.

44"The woman's great fame had spread throughout all Asia, and the name of Callirhoe was now making its way to the Great King, outstripping that of Ariadne or of Leda."

${ }^{45}$ This is the canonical version, as found in, for example, Catull. 64.50-264 (251-253 for Bacchus/Dionysus), Ov. Met. 8.172-179, Nonnus, Dion. 47.268-469, and traccable as far back as

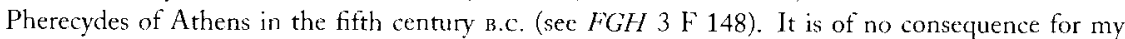
general argument that Eur. Hipp. 339 apparently alludes to the (rather murky) alternative tradition in which Ariadne left Dionysus for Theseus, as a result of which she was killed by Artemis (see Hom. Od. 11.321-325) (on this see Barrett 1964: 222-223); the intertextual links between the play and $C E C$ do not depend on exact correspondences in other common elements. 
Which of the gods has become ny rival in love and carried off Callirhoe and now has her with him ... ?... In just this way Dionysus stole Ariadne from Theseus ${ }^{4 t}$ and Zeus Semele. (3.3.4-5)

For Reardon, ${ }^{47}$ the point of the comparison is that Ariadne and Semele were transformed into divinities (Chaereas' next remark is that he must have had a goddess for a wife without knowing it); this is entirely rcasonable, but we should not ignore the male side of the comparison either, which confirms Chaereas' identity as a Theseus-figure. The wordplay on Dionysus/Dionysius in this passage also holds an irony. ${ }^{+8}$ Chaereas does not yet know of Dionysius and his marriage to Callirhoe, which has taken place a page before; the reader does.

Finally, and perhaps most tellingly, a second scene in the novel is reminiscent of action in the Hippolytus. Like all the other men of high station in the work, the King of Persia, Artaxerxes, falls in love with Callirhoe and asks his minister, the eunuch Artaxates, to find a remedy ( $\phi \dot{\alpha} p \mu \alpha \kappa o v$ ) for his love. The eunuch replies that "there is no other pharmakon for love except the loved one"49 (6.3.7). This exchange recalls the scene in Euripides' play where Phaedra's nurse, to save her mistress from death, urges her to surrender to her passion for Hippolytus. At the end of her speech of persuasion (Hipp. 433-481) the nurse speaks ambiguously

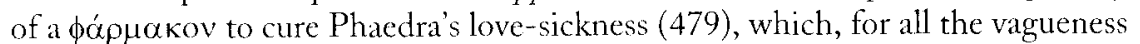
and ambiguity of her language, we should in the context ${ }^{50}$ understand (as Phaedra clearly does, 486-489) to refer to a means of achieving Hippolytus' love in return, even indeed to Hippolytus himself (cf. 699, where the reference is unmistakable); at 516 Phaedra herself uses the word, in response to further ambiguous utterances by the nurse about love-charms. ${ }^{51}$ Artaxates' reply to the king could not be more unambiguous, but his intention is the same as the nurse's: to procure the object of desire for the person he serves. He also stands in the same kind of relation to the king as the nurse to Phaedra: the role is that of an inferior who is also

4h The text here reflects it different version of the Ariadne story from that evident at 8.1.2; cf. Diod. Sic. 4.61.5, Paus. 10.29.4, Apollod. Epit. 1.9, and perhaps Ath. 7.47 (296a), referring to an episode in the Bachica of Theolytus of Methymna. The attempt of Cucva 1996 (essentially identical to Cueva 2004: 16-24) to establish Plut. Thes. $19-20$ as a specific source for the Ariadne elements (and various other details) in $C \mathcal{S}^{\circ} \mathrm{C}$ is unconvincing; among other reasons, the detail of the theft in the present passage has no counterpart in the These'us.

47 Reardon 1989: 53, n. 51.

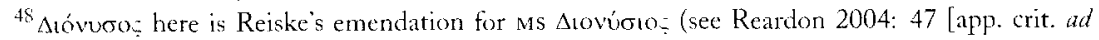
loc.]); the wordplay seems certain.

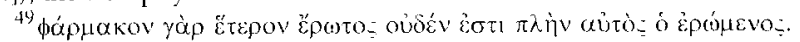

${ }^{50}$ And particularly in the light of the nurse's explicit assertion at 490-491 about Phaedra needing "the man."

${ }^{51}$ Given that the nurse is not actually planning to usc any kind of love-magic, but to make a direct approach to Hippolytus (hence her ludicrous reply oun ois'-to Phaedra's question about the nature of the supposed magic drug [516-517]; she has been blathering, and is caught by surprise by the

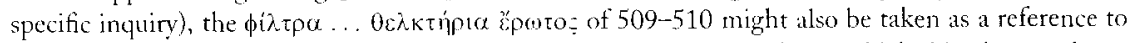
her coming attempt to win Hippolytus over (the $\lambda \hat{y}$ os $0 c \lambda \kappa \tau$ inpto of 478 , which this phrase echoes, similarly gain a retrospective gloss from the action that follows). Cf. Gotf 1990: 48-54. 
a confidant. His implicit suggestion horrifies the king, who rejects absolutely

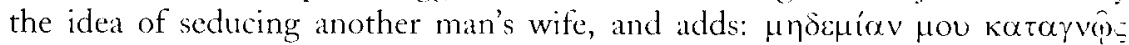

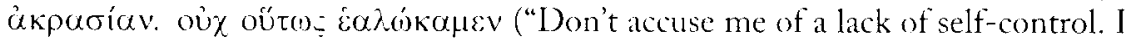
am not overcome to that cxtent," 6.3.8). akparia here should remind us of that

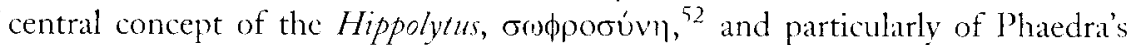

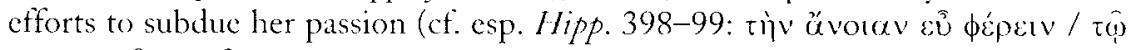

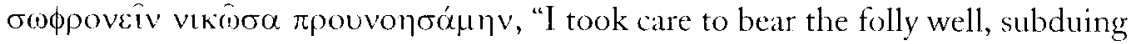
it with sopbrosune"). Shifting his ground, Artaxites encourages the king not to apply the usual remedy for his love but to fight against himself, distracting his

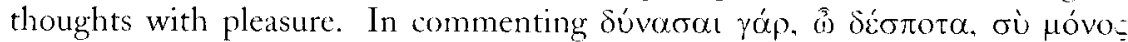

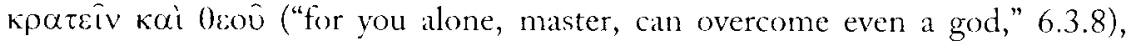
Artaxates inverts the tactic of Phaedra's nurse, who tells the queen that Kútots

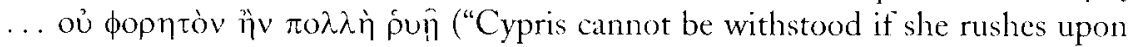

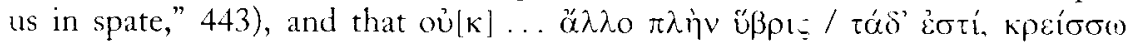

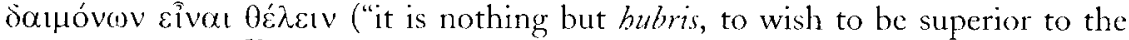
gods," 474-475) ${ }^{53}$ His specific suggestion is that the king go hunting:

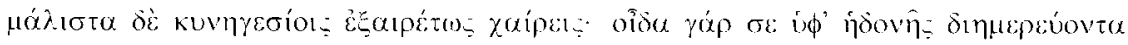

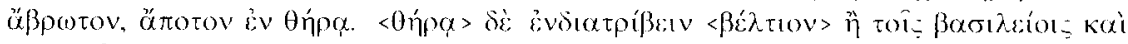

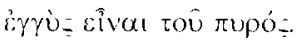

You take very great pleasure in hunting in particular; indeed, I know that you spend the entire day without food or drink when you go hunting, you enjoy it so much. It is better to spend your time hunting than in the palace and close to the fire. (6.3.9)

Now while hunting is the kind of thing which Persian kings in Greek literature regularly do ${ }^{54}$ and its use as a means of counteracting love became something of a topos in Roman poetry in particular, ${ }^{55}$ it is also the activity of the chaste Hippolytus par excellene; and of course it is one of the activities in which Phaedra expresses a wish to engage in the episode of her wild fantasies early in the play

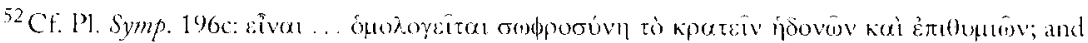
esp. Arist. Fith. Nic. 7.1-10) (for the correlation of the pairs of opposites akpuria/erypatsace and

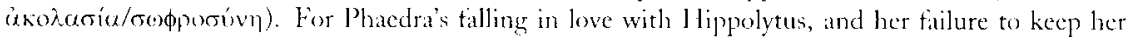
sceret from the nurse, ats akpuria, see Stinton 1975: 247 (=1990: 176); of. alsu Caims 1993: 338. ocopporiven in the /Iippolytu: has recently been discussed by Rademaker (2005: 16.3-1.73).

Ny thanks to Simon (soldhill for peinting ne towards this connection. With Artaxites words at 6.3 .8 ct. also /lipp. 400-4(1)1, where Phaedra, reviewing how she hats attempted to deal with her

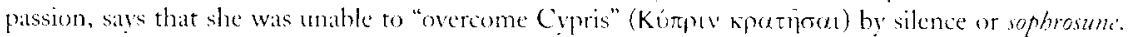
The notion of sophrowne as bubic (normally the terms are antithetical), implicit in Hipp. 474-475. finds a sharp parallel at CEC: 2.4 .5 , where Eros reaction to I ) ionssius' attempts to suppress his desire

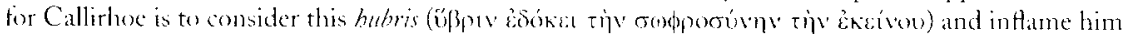
all the more; on this of. Balot 1998: $1+7$.

${ }^{4}$ See esp. Xenophon's Coropatiar (c.g. 1.2.9-10, 1.4.5-15, 2.4.16-21), but also, for example,

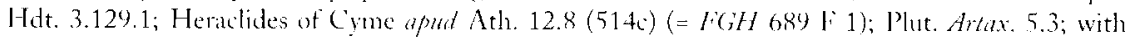
J. K. Anderson 1985: 58-6.3; 1 ance Fox 1996: 123, 1+()-1+1.

${ }^{55}$ See, for example, Virg. Kal. 10.56-60); Hor. Epod. 2.29-38. Or. Rim. am. 199-206; and ef. Xen. Cin, 5.33 . 
(Hipp. 215-222), and in the scene in Chariton, as we have observed, Phaedra's is the role taken by the king. ${ }^{56}$ The reference in the above passage to going without food may also draw on the words of the chorus at Hippolytus 135-138, where they sing how it is now the third day since Phaedra has eaten:

$$
\begin{aligned}
& \tau \rho i ́ \tau \alpha \tau \alpha \vee \delta \dot{\varepsilon} \text { vIV } \kappa \lambda \dot{u}(1)
\end{aligned}
$$

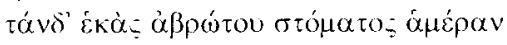

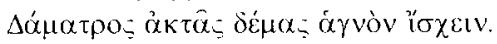

I hear that for three days now, her mouth taking no food, she has kept far off the holy substance of Demeter's grain.

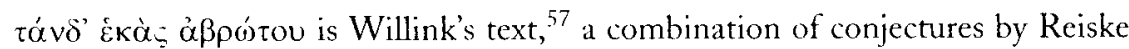

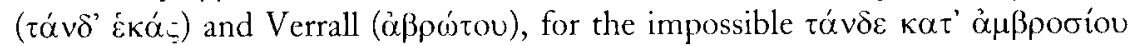
of the manuscripts; ${ }^{58}$ Barrett and Diggle ${ }^{59}$ follow Hartung's tó $v \delta \delta^{\prime} \alpha \beta \rho \omega \sigma i \alpha$, the

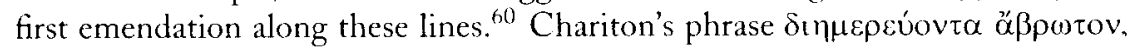

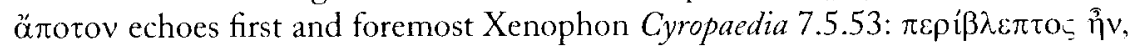

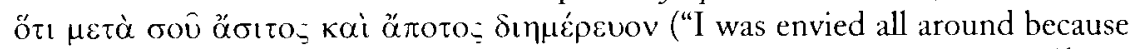
I was spending a whole day with you-without anything to eat or drink"); ${ }^{61}$ but $\alpha \beta \beta \rho \omega \tau-$ does not occur in that work, and it seems highly likely that the novelist's $\alpha \alpha \beta \rho \omega r o v-a$ word less frequently and widely found than $\alpha$ or to rare in an active sense ${ }^{62}$ - was prompted by the passage in the Hippolytus. ${ }^{6.3}$

Some comment on the reading process involved in disclosing the presence of the Hippolytus in Chaereas and Callirboe may be useful at this juncture. At 296 above, I wrote of the reference to Hippolytus at Chaereas and Callirboe 1.1.3 as the "trigger" for recognition of the Euripidean intertext in the scene of Chaereas'

${ }^{56}$ Plepclits (1976: 183, n. 48) and Goold (1995: 297, n. b) offer Hipp. $215 \mathrm{ff}$. as a parallel to the Chariton passage on the ground that-like the passages cited above, 303, n. 55-it presents hunting as an antidote to love. The more usual view is that Phaedra is expressing a desire to be in the places frequented by Hippolytus and taking part in his pursuits (for a summary of critical opinion, sec Goff 1990: 32-34); on this interpretation, recognition of the intertext will suggest that the eunuch's schene will fail, as indeed it does-far from distracting the king, the hunt causes his passion to flare up violently, through the intervention of the god Eros ( $C B^{\circ} C$ 6.4.4-7).

${ }^{57}$ Willink 1968: 37; he is followed by Kovacs (1995), whose colometry and translation 1 also give.

58 On the manuscript reading, see Barrett 1964: 187.

${ }^{59}$ Barrett 1964; Iiggle 1984; so too Stockert 1994.

${ }^{60}$ Hartung 1848.

${ }^{61}$ For the frequent cchoes of the Cyropadia in Chariton, see Papanikolaou (1973: 19-20), who observes the present borrowing.

${ }^{62}$ A search of the Thesaums linguae Gratae online undertaken on 17 July 2007 generated (as raw data) 113 instances of $\alpha \beta p o t 0_{5}$ in Greek up to and including the sccond century A. D., against 154 for ärito; much more significant is the fact that of those 113 instances only two cvidently bear an active sense ("not eating," rather than "inedible" or "not eaten"): the Chariton passage discussed here and Soph. fr. 967 Radt, which depends on very sketchy evidence in the Onomastion of Pollux (6.39; for Euripides, the $7 I, G$ presents I iggle's text).

${ }^{63}$ Where note too itupexv. The Chariton passage and its context offer excellent substantiation for Verrall's conjecture; 1 shall discuss the whole matter more fully in a further article. 
assault. Located at the beginning of the novel, and in a context disposed to activate the reader's generic consciousness, the reference offers a clear pointer towards coming engagement with Euripides' play; and this engagement appears a few pages later, to be reinforced by the subsequent connections I have identified. But in fact identification of the intertext does not depend on a unidirectional reading. The awakening of an intertextual awareness is a complex process in which the reader may follow any number of paths; to put this differently, there is not one trigger, but many. The uncovering of the Euripidean intertext may begin with any of the details to which I have drawn attention (or some other which I have not observed), so that (for example) the recognition of the scene of Theseus' curse beneath the assault scene in Chaereas and Callirhoe may either stimulate or follow the recognition of significant details associating the two texts elsewhere in the novel; even my initial trigger at 1.1 .3 might be the final intertextual element to be identified. The fundamental point is that the individual threads in the intertextual web are mutually supportive; it is the accumulation of links that gives strength to each and to all. ${ }^{64}$

Two scenes in Chaereas and Callirhoe, then, can claim to be modelled on scenes in the Hippolytus of Euripides. ${ }^{65}$ In the second, the model is made subject to gender inversion (two men take the roles of two women) and, as the scene proceeds, to reversal in the role of the character of lower status: the nurse blusters and conceals her true intentions, but never seriously adopts a different policy towards Phaedra, while the eunuch at this point (later he encourages the king's desire for Callirhoe ${ }^{66}$ ) seeks to assist the king to overcome his feelings. Recognition of the intertext points to potential tragic consequences, for the desiring subject (the king/Phaedra), the object of desire (Callirhoe/Hippolytus), or both; in the event - in the way of the Greek romantic novel-such consequences do not ensue, though the king's desire for Callirhoe remains unfulfilled and he experiences defeat in war at the hands of a rebel army led by Chacreas. This tragic potential, however, should not be ignored; I shall return to this in a moment.

\footnotetext{
${ }^{64}$ For further helpful observations on the kind of reading process I outline here, see Gale 2000: $15-17$.

${ }^{6.5}$ Kaimio (1996: 56-57) also points to similarities in Chariton's presentation of the response of Dionysius to falling in love with Callirhoe early in the novel (concealment [2.4.1], attempted suppression through self-discipline [2.4.4], resolve to commit suicide [2.6.2, 3.1.1]) and Euripides' depiction of Phaedra in the Hippolytus (see esp. 391-402); she also draws attention to the role played by servants in both cases. In Kaimio's vicw, these similarities "may be conscious reflections." We can at all events see here a double use of the Euripidean model-which, given that the characters of the king and Dionysius have much in common, especially in their reactions to the assaults of Eros, should not surprise us-but in my judgement the model is much more evident in the case of the king: the density of influence in the scene just discussed $(C E C$ 6.3.7-9) is far greater than in the sequence with Dionysius, where the echoes are diluted owing to their being distributed through a much longer portion of text (the better part of Book 2 , and into Book 3 ).

${ }^{\text {th }} \mathrm{Sec}$ esp. $C \mathcal{E}^{\circ} \mathrm{C} 6.4 .7-8$. In making approaches to Callirhoe on the king's behalf $(6.5,6.7)$ the cunuch again acts in a parallel way to the nurse in the Hippolytus, with the difference, of course, that this is done with the approval (indeed at the command) of his master.
} 
But the more striking and more important intertextual connection between Chaereas and Callirboe and the Hippolytus is that involving the scenes of Chaereas' assault and Theseus' curse. As I have said, the assault scene is absolutely central in the development of the plot of the novel. The parallel with the Hippolytus is also closer than that with its comic counterpart in Menander's Perikeiromene in two important respects. First, the false information which triggers the act of anger is in Chacreas and Callirboe and Euripides' play deliberately conveyed to the perpetrator for malicious purposes: the suitors stage the apparent love affair and set up Chaereas, Phaedra leaves her lying message for Theseus. In Menander, by contrast, there is only misunderstanding. Sccondly, Polemon's act of cutting his mistress' hair is clearly of an altogether different order from Chaereas' kick to the stomach and Theseus' curse, and carries far less risk of catastrophic consequences. ${ }^{67}$

As I made clear earlier, this is not, of course, to deny a comic as well as a tragic model for the scene in Chariton. In his stimulating discussion of the relationship of Chaereas and Callirhoe to classical and post-classical historiography Hunter draws attention to this episode from the Perikeiromene, ${ }^{68}$ and later seeks to demonstrate how "this sequence of action is crucially integrated into Chariton's concern with history and historicity. " ${ }^{69}$ In his analysis he alerts us, inter alia, to a range of texts which preserve stories of historical figures striking their pregnant wives in anger (Callirhoe is, as it later turns out, pregnant), the legal situation regarding adulterers caught in the act in fifth-century Athens, and the position assumed in respect of such cases in Greek and Roman declamation; and concludes with the view that Chariton has deliberately problematized what "code" should be used when we read the scene-historical? comic? rhetorical/declamatory? "Rather," says Hunter, "we must recognise in this scene an interplay of various codes which, and this is crucial, we are supposed to recognise" (his italics). ${ }^{70}$ Though I would state this in a less intentionalist way, I am in absolute agreement with the fundamental point being made; and to Hunter's categories I would add "tragic."

The evocation of the Hippolytus in the assault scene in Chaereas and Callirhoe, so important in the narrative, invites us to read this episode as serious tragedy ${ }^{71}$ -

${ }^{67}$ It is worth noting at this point a possible direct link between the Iifpolytus and the Perikeiromene. In both there is a divine (or quasi-divinc) level of causation, Aphrodite controlling the action of Euripides' play, Agnoia (Misconception or lgnorance)-who similarly delivers a prologue promoting Polemon's act of rage (but with good intent) in Menander's (see Pk. 162-170). (One might also compare the malicious daimon which lies behind the sutors' plot in CSGC [sec 1.1.16], though this figure is far less prominent.) And the presence of the "goddess" Agnoia herself may echo the action of the Hippolytus as well as supporting the suggestion of Menandrcan influence on Chariton.

68 See above, 294, n. 16.

${ }^{69}$ Hunter 1994: 1079.

${ }^{70}$ Hunter 1994: 1082.

${ }^{71}$ Tragic qualitics in the episode as at whole are also noted by (icu (1982: 125-129), examining it through the lens of Aristotle's Poctics, he does not, however, make connections with specific plays. 
which is not at all to exclude our reading it in other ways.' Generically (and because the author has provided hints that there is going to be more ${ }^{73}$ ) we mav know that the tragedy will be temporary, but familiarity with normal closural patterns in genre does not suck out all emotional life from a text. Until we reach the end we can never be completely certain that the expected conclusion will result, and if Chariton's work represents an early stage in the history of the ancient novel ${ }^{\text {it }}$ expectations may in any case have been less clear; besides, tension can be experienced even in the course of reading a text we have read before, when we are absolutely certain of the outcome-we may know that Oedipus will find out the truth about himself in Oedipus Tyranmus, but we are still capable of engaging emotionally in resistance to his drive to do so as the action proceds. Again-and this is something of which we should not lose sight-among the perspectives offered by a text is the perspective of the characters, and from the point of view of Chacreas and all the people of Syracuse the consequences of the assault on Callirhoc are utterly tragic. Some sense of the emotional complexity to be found here may be acquired by looking at a much later play, the Shakespearean comedy

\footnotetext{
$7^{2}$ Paulien (1992: 85-102) takes a slightly different approald in considering the generic (or modal) complexity of Cnemon's story in the Aethiopica of the much later novelist Heliodorus (Aeth. 1.9-17), but comparison may be illuminating. In latulsen's andysis this episode, an instantiation of the common "Potiphar's Wife" story-type most familiar in Greck literature in the form of the l'hatedra/Hippolytus legend (which Heliodorus explicitly evokes, and with specific reference to tragedy Isee Atth. 1.8.7, 1.10.2]; an unmistakihle verbal ccho of Eur. Hipp. 802 is also evident at $A t h .8 .15 .2$, in the context of a second reworking of the legend), can be seen to possess a tragic chatacter, which is, however, anderat by the presence of comic elements. In this article I offer a different sort of solution to the generic problem raised by the assault scene in $C \mathcal{G} C$, but the two approaches are in accord in underlining the point that generically these are slippery texts which refuse the reader easy purchase. It may be added here that Cnemon's story in Heliodorus novel displays interesting and complex links with the cpisode of the suitors' plot and Chaereas' assault on Callirhoe in CSC': note, for example, the accusation made by the Phacda-figure, Demainete, who claims to be pregnant, that she has been kicked by the Hippolytus-figure, Cnemon (Acth 1.10.4); the evocarion of Theseus' anger (Ath. 1.11.1-2); and the plot with deliberate misinformation which results in Cnemon, in anger, bursting in upon Demainete and her alleged lover in the bedroom, with the intent of killing them $(A v t b, 1.11 .3-12.4)$.

${ }^{73}$ In the first sentence of the novel (CEC 1.1.1) Chariton states that he is going to tell a love

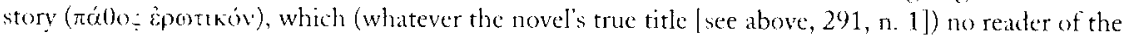
opening chapters is likely to take to be anything other than that of Chicereas and Callirhoc-which can hardly end so soon. More specifically, the careful wording at 1.5.1, where Callirhoe "present[s] to all the appearance of a corpse" (sec above, 294, n. 15), provides the attentive reader with a firm clue that she is not actually dead.

${ }^{74}$ Dating is uncertilin; the broad consensus now is that it belongs to the second half of the first century A.D. or possibly the first decades of the second, though it could be carlier. In any event, with rare exceptions (most notably () Sullivan 1995: 145-170, who argues for the priority of Xenophon's Ifthesiaca), it is accepted that $C \Theta C$ is the carliest of the five extant Greek novels. For at recent summary of scholarly positions and arguments concerning (hariton's date, sec Cueva 2000; and for a fresh discussion of the dating of CEC, the fragmentary novel texts Ninus and Metiochus and Parthope, and Xenophon's Ephestaca, Bowie (2002: 47-58), who argues that all were probably written within the space of a few decades in the mid-and late first century A.D., and tentatively proposes termini of 41 and 61 or 62 for Chariton.
} 
Much Ado About Nothing, where the Claudio-Hero plot offers striking similarities to the assault episode in Chariton, with undoubted tragic colour. ${ }^{75}$

None of this, of course, is intended to suggest that Chariton's novel as a whole is to be regarded as having a tragic character; but neither is it true to say, with Reardon, "there is not even a glimpse of tragedy." 76 Indeed, the existence of an expressly tragic dimension to the work may be thought to be implied by the apparent allusion to Aristotle's doctrine of catharsis (Poet. 6 [1449b]) early in the last book, where the narrator, addressing his readers in the first person in a kind of internal prologue, expresses his belief that they will find the final

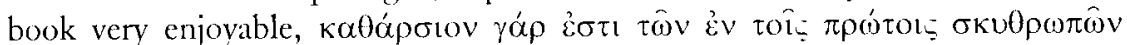
("for it washes away the gloomy events in the earlier books," 8.1.4). ${ }^{77}$ Whether this reflects a misunderstanding or "trivialization" of the Aristotelian passage, or testifies to a less accepted interpretation of it, ${ }^{78}$ it directs us towards reading the novel in partly tragic terms ${ }^{79}$-even if the tragedy it invokes is (necessarily) of the "catastrophe survived" type. As far as more "tragic" tragedy is concerned, I suggested earlier (292) that the critical emphasis on the influence of comedy on the Greek novel may have led to the failure to perceive intertextual connections between the novel and such works, a kind of critical blind spot. But the greater responsibility lies with the history of scholarship on the novel since Rohde, ${ }^{80}$ the

${ }^{75}$ The key points of contact are the duping of the male lover (Claudio) into believing that the beloved (Hero), whom he is to marry, is unfaithful; the means used in effecting the ruse (the apparent affair is "staged" for Claudio - who has been primed with the false information-to see with his own eyes, and a female servant of the heroine is involved in both cases); and the accusation hurled at Hero by Claudio at their wedding, which results in her swooning and apparent death. Claudio's remorse on learning that he has been tricked can similarly be compared with Chaereas' wish to die when the truth about Callirhoe's innocence has been revealed ( $C E C$ C $1.5 .2,1.5 .4-5,1.6 .1$ ); both still believe their beloved to be dead. In the case of Muh Ado, the audience is assured moments after the assault that Hero is not in fact dead; but this does not, in my judgement, diminish the sense of tragedy inherent in the assault scene and in Claudio's subsequent regret and mourning, with which we can still fully empathize. The Shakespearean story finds close analogues in a number of earlier Renaissance texts, and while the lines of influence are impossible to establish with precision, the hypothesis that $C \& C$ lies at the back of the tradition is plausible and attractive; see the discussions of Weichberger 1898; Gesner 1970: 64-70; Mason 1998

${ }^{76}$ Reardon 1982: 24 (= Swain 1999a: 185).

${ }^{77}$ The association with pleasure of course reinforces the Aristotelian connection; see esp. Poet. 14 (1453b), with Müller 1976: 134-135, who also rightly draws attention to the firther implication of the Chariton passage that readers will have derived pleasure from the carlier parts of the narrative-the

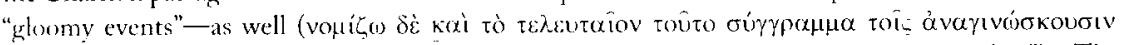

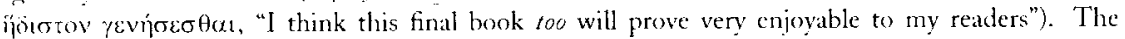
relation of the Greek novel to Aristotle's analysis of tragedy in the Pottics generally is considered in some detail by Cicu (1982, csp. 115-135), with considerable emphasis on Chariton; Reardon 1988: 205-211; Reardon 1991: 77-83, 100-106.

${ }^{78}$ See Müller 1976: 134-135; Rijksbaron 1984.

${ }^{79} \mathrm{~A}$ conclusion which scholarship has been reluctant to draw; the possible wider implications of the allusion have routinely been ignored.

${ }^{80}$ Rohde 1876. 
attitude of disdain towards these texts - particularly the so-called "presophistic" or "non-sophistic" 81 examples (Chariton, Xenophon of Ephesus)-from which we have begun to emerge but have still not entircly escaped, ${ }^{82}$ and which resists the serious association of the novel with "high" genres. Recognition of the scenes in Chacreas and Callirbo which echo Euripides' Hippolytus reveals the tragic potential in the work, and this should both complicate and enrich our response to it $^{8.3}$ and give us further encouragement towards a more generous estimation of this novel and its genre. Such recognition also marks the passage at 1.1.3, where the initial comparison between Chaereas and Hippolytus is made, ${ }^{84}$ as more strongly programmatic than has hitherto been observed; and this should alert us to the possibility that other tragic intertexts lurk beneath the surface of Chariton's romance.

Department of Ancient Classics

National University of Irfi,and, Maynooth

MaYnoOTh

Co. KIIDARF

IRELAND

david.scourfield@nuim.ie

BIBLIOGRAPHY

Allen, D. S. 2000. The World of Promethers: The Politics of Punishing in Democratic Athens. Princeton.

Anderson, J. K. 1985. Hunting in the Ancient World. Berkeley, Los Angeles, and Iondon. Anderson, W. S. 1957. "Vergil's Second Iliad", TAPA 88: 17-30 (repr. in Harrison 1990: 239-252).

${ }^{81}$ The distinction between "sophistic" and "pre" or "non-sophistic" is pervasive in scholitship on the novel: sec, for eximple, Perry 1967: 108-109; Ilizgs 1983: 34; Ruiz-NIontero 1996: 30. In the case of "presophistic," the distinction is collapsed by Swan (1999b: 27-28). See further below, n. 82.

${ }^{82}$ In recent years the residue of Rohde's disdain hals perhaps been most evident in the association of the writings of Chariton and Xenophen in particular with terms normally applied to modern

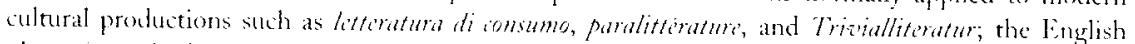
phrase "popular literature" strikes me as less damning, though an implicit hierarchy of texts is evident here too. My point is not that adhesion $t$, or the construction of, such hierarchies is in itself (as it were) morally reprehensible (it may indeed be unavoidable, to some degree), but that it can be critically deleterious to texts placed in lower positions on the ladder, predisposing us to think that they contain little of interpretative interest. In the calse of the (inects novel, the distinction mentioned above between "sophistic" and "pre-" or "mon-sophistic" similarly imposes a judgement which, if by certiin criteria reasonable, nevertheless tends to a shecp-and-goats classification. For the application (and consideration of the applicability) of the term litsowat di consumo and its equivalents to (ireek novel texts, sece esp. Fisillo 1994, 1996; Briuso Sáncher 2000, 2001.

"Cf. Kamio 1996: 57 , on the Metal echo (sec above, 292, n. 10) and the reflections of the Ifippolyzus in Dionysius" reaction to falling in love with Callirhoe (see above, 305, n. 65): "Such cascs of tragic intertextuality should not be regarded als mere embellishments, but as a means of emphasizing the serious nature of the conflict."

${ }^{84}$ Above, 296. 
Arnott, W. G. ed. 1996. Menander 2. Cambridge, M $\Lambda$ and l,ondon.

Balot, R. K. 1998. "Foucault, Chariton, and the Masculine Self," Helios 25: 139-162.

Barrett, W. S. ed. 1964. Euripides: Hippolytos. Oxford.

Bartsch, W. 1934. Der Charitonroman und die Historiographic. Diss., Leipzig.

Billault, A. 1996. "Characterization in the Ancient Novel," in Schmeling 1996: 115-129.

- 1998. "Les romanciers grees et la tragédie," in Le' théatre grec antique: La tragédie.

Actes du sème colloque de la Villa Kérylos à Beaulieu-sur-Mer les 3 et 4 octobre 1997, sous la présidence et la direction de Jean Leclant et la direction de Jacques Jouanna. Cahiers de 1a Villa Kérylos 8. Paris. 179-194.

Borgogno, A. 1971. "Menandro in Caritone," RFIC 99: 257-263.

Bowic, E. L. 2002. "The Chronology of the Earlier Greek Novels since B. E. Perry: Revisions and Precisions," Ancient Narrative 2: 47-63.

Brioso Sánchez, M. 2000. "¿ralidad y literatura de consumo en la novela griega antigua?: Caritón y Jenofonte de Éfeso (I)," Habis 31: 177-217.

— 2001. "¿ralidad y literatura de consumo en la novela griega antigua?: Caritón y Jenofonte de Éfeso (11)," Habis 32: 425-461.

Cairns, D. L. 1993. Aidōs: The Psychology and Etthics of Honour and Shame in Ancient Greek Literature. Oxford.

— 1996. "Hybris, Dishonour, and Thinking Big," JHS 116: 1-32.

- 1997. "The Meadow of Artemis and the Character of the Euripidean Hippolytus," QUCC N.s. 57: 51-75.

Cicu, L. 1982. "La poetica di Aristotele e le strutture dell'antico romanzo d'amore e d'avventure," Sandalion 5: 107-141.

Corbato, C. 1968. "Da Menandro a Caritone: studi sulla genesi del romanzo greco e i suoi rapporti con la commedia nuova (I)," Quaderni triestini sul teatro antico 1: 5-44.

Cueva, E. P. 1996. "Plutarch's Ariadne in Chariton's Chacreas and Callirboe," AJP 117:

473-484.
-2000. "The Date of Chariton's Chacreas and Callirhoe Revisited," CIMed 51: 197-208.

- 2004. The Myths of Fition. Studies in the Canonical Greek Novels. Ann Arbor.

Diggle, J. ed. 1984. Euripidis Fabulat 1. Oxford.

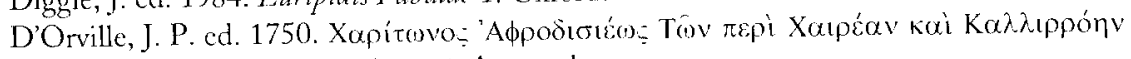

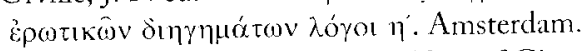

Fowler, D. P. 1997. "On the Shoulders of Giants: Intertextuality and Classical Studies," MD 39: 13-34 (repr. in Fowler 2000: 115-137).

- 2000. Roman Constructions: Readings in Postmodern Latin. Oxford.

Fusillo, M. 1989. Il romanzo greco: polifonia ed eros. Venice.

- 1994. "Lettcratura di consumo e romanzesca," in G. Cambiano, L. Canfora, and D. Lanza (eds.), Lo spazio letterario della Grecia antica 1: La produzione e la circolazione del testo 3: I greci e Roma. Rome. 233-273.

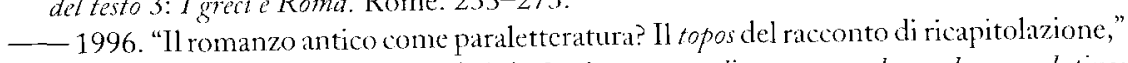
in O. Pecere and A. Stramaglia (eds.), La letteratura di consumo nd mondo greco-latino: Atti del convegno internazionale, Cassino, 14-17 settembre 1994. Cassino. 47-67.

- 1997. "How Novels End: Some Patterns of Closure in Ancient Narrative," in D. II.

Roberts, F. M. Dumn, and D. Fowler (eds.), Classical Closure: Reading the End in Greek and Latin Literature. Princeton. 209-227. 
Gale, M. R. 2000. Virgil on the Nature of Things: The Georgics, lucretius and the Didactic Tradition. Cambridge.

Gerschmann, K.-H. 1974. Chariton-Interpretationen. Diss., Münster.

Gesner, C. 1970. Shakespeare and the Greek Romance: A Study of Origins. Lexington.

Goff, B. E. 1990. 'The Noose of Words: Readings of Desire, Violence and Language in Euripides' Hippolytos. Cambridge.

Goold, G. P. ed. 1995. Chariton: Callirhoe. Cambridge, MA and I ondon.

Hägg, T. 1971. Narrative Technique in Ancient Greek Romances: Studies of Chariton, Xenophon Ephesius, and Achilles Tatius. Acta Instituti Atheniensis Regni Sueciae, Series in $8^{\circ}, 8$. Stockholm.

- 1983. The Nonel in Antiquity. Engl. tr. Berkeley and Los Angeles.

Halleran, M. R. ed. 1995. Eirripides: Hippolytus. Warminster.

Hammer, S. 1922. "De annatoriis Graccorum fabulis observationes," in Charisteria Casimiro de Morawski septmagenario oblata at amicis, collegis, discipulis. Cracow. 88-123.

Harris, W. V. 2001. Restraining Rage: The Ideology of Anger Control in Classical Antiquity. Cambridge, MA and London.

Harrison, S. J. ed. 1990. Oxford Readings in Vergit's Aeneid. Oxford and New York.

Hartung, J. A. 1848. Euripides' Werke 3. Leipzig.

Hinds, S. 1998. Allusion and Intertext: Dynamias of Appropriation in Roman Poetry. Cambridge.

Hirschberger, M. 2001. "Epos und Tragödic in Charitons Kallirboe: ein Beitrag zur Intertextualität des griechischen Romans," WJA 25: 157-186.

Holaberg, N. 2001. Der antike Roman: Fine Einfiubrung ${ }^{2}$. Düsseldorf,

Hunter, R. 1994. "History and Historicity in the Romance of Chariton," ANRW II.34.2: 1055-86.

Kaimio, M. 1996. "I Iow to Enjoy a Greek Novel: Chariton Guiding his Audience," Arctos 30: 49-73.

Kapparis, K. 2000. "Has Chariton Read Lysias 1 'On the Murder of Eratosthenes'?," Hermes 128: 380-383.

Knox, B. M. W. 1952. "The Hippolytus of Euripides," YCS 13: 3-31.

Kovacs, D. ed. 1995. Euripides 2. Cambridge, MA and London.

Lane Fox, R. 1996. "Ancient Hunting: From Homer to Polybios," in G. Shipley and J. Salmon (eds.), Human Landscapes in Classical Antiquity: Environment and Culture. Leicester-Nottingham Studies in Ancient Society 6. London and New York. 119-153.

Laplace, M. 1980. "Les légendes troyennes dans le 'roman' de Chariton, Chairéas it Callirboc," REG 93: 83-125.

Liapis, V. J. 2006. "Achilles Tatius as a Reader of Sophocles," CQ N.s. 56: 220-238.

Lowe, N. J. 2000. The Classical Plot and the Invention of Western Narrative. Cambridge.

MacDowell, D. 1968. "Unintentional Homicide in the Hippolytos," RbM N.F. 111: 156-158.

Marini, N. 1993. "ll personaggio di Calliroe come 'nuova Elena' e la mediazione comica di un passo euripideo (Charito III 10-IV 1 = Hol. 1165-1300)," SIFC 11: 205-215.

Mason, H. J. 1998. "Genealogy of a Frame-Up," Canadian Journal of Italian Studies 21: 1-15.

- 2002. "Chaireas in Chariton and New Comedy," Classical Bullitin 78: 21-27. 
Morgan, J. R. 1993. "Make-Believe and Make Believe: The Fictionality of the Greek Novels," in C. Gill and T. P. Wiseman (eds.), Lies and Fiction in the Ancient World. Exeter. 175-229.

Morgan, T. 1998. Literate Educution in the Hellenistic and Roman Worlds. Cambridge.

Müller, C. W. 1976. "Chariton von Aphrodisias und dic Theorie des Romans in der Antike," $A \circlearrowleft A 22: 115-136$.

O'Sullivan, J. N. 1995. Xenophon of Ephesus: Itis Compositional Technique and the Birth of the Nowel. Untersuchungen zur antiken Literatur und Geschichte 44. Berlin and New York.

Papanikolaou, A. D. 1973. Chariton-Studien: Untersuchungen zur Spracbe und Chronologie der griechischen Romane. Hypomnemata 37. Göttingen.

Paulsen, T. 1992. Insz'nicrung des Schickals: Tragödie und Komödi' im Roman des Heliodor. Bochumer Altertumswissenschaftliches Colloquium 10. Tricr.

Perry, B. E. 1967. The Ancient Romances: A Literary-Historical Account of Their Origins. Sather Classical Lectures 37. Berkelcy and I os Angeles.

Plepelits, K. tr. 1976. Chariton onn Aphrodisias: Kallirboe. Bibliothek der griechischen Literatur 6. Stuttgart.

Porter, J. R. 2003. "Chariton and Lysias 1: Further Considerations," Hermes 131: 433-440.

Rademaker, A. 2005. Sophrosyne and the Rhetoric of Self-Restraint: Polysemy and Persuasive Use of an Ancient Greek Valuc Term. Mnemosyne Supp. 259. Leciden and Boston.

Reardon, B. P. 1982. "Theme, Structure and Narrative in Chariton," YCS 27: 1-27 (repr. in Swain 1999: 163-188).

_ - 1988. "The Form of Ancient Greek Romance," in R. Beaton (ed.), The Greek Novel a.1) 1-1985. London. 205-216.

- ed. 1989. Collected Ancicht Greek Nowels. Berkelcy, Los Angeles, and London.

- 1991. The Form of Greek Romance. Princeton.

— 1996. "Chariton," in Schmeling 1996: 309-335.

—_ ed. 2004. Chariton Aphrodisionsts: De Callirboe narrationes amatoriae. Munich and Leiprig.

Reitzenstein, R. 1906. Hellenistische Wundererzäblungen. Leipzig.

Rickert, G. 1989. "Fko)v and ökov' in Early Grek Thought. American Classical Studies 20. Atlanta.

Rijksbaron, A. 1984. "Chariton 8, 1, 4 und Aristot. Poet. 1449 b 28," Philologus 128: 306-307.

Robiano, P. 1984. "I a notion de Tychè chez. Chariton et che" Héliodore," REG 97 : $543-549$.

Rohde, E. 1876. Der griechische Roman und seine Vorläufor. Leipzig.

Ruiz-Montero, C. 1996. "The Rise of the Greek Novel," in Schmeling 1996: 29-85.

Schmeling, G. L. 1974. Chariton. New York.

- ed. 1996. The Novet in the Ancient World. Mnemosyne Supp. 159. Leciden, New York, and Cologne.

Scourfield, J. H. D. 2003. "Anger and Gender in Chariton's Chaereas and Callirboe" in S. M. Braund and G. Most (eds.), Ancient Anger: Perspectives from Homer to Galen. Yale Classical Studies 32. Cambridge. 163-184.

Smith, S. D. 2007. Greek Identity and the Athenian Past in Chariton: The Romanic of Empire. Anciont Narratio' Supp. 9. Groningen. 
Stinton, T. C. W. 1975. "Hamartia in Aristotle and Greek Tragedy," CQ N.s. 25: 221-254 (repr. in Stinton 1990: 143-185).

- 1990. Collected Papers on Greek Tragedy. Oxford.

Stockert, W. ed. 1994. Furipides: Hippolytus. Stuttgart.

Swain, S. ed. 1999a. Oxford Readings in the Greek Novel. Oxford.

- 1999b. "A Century and More of the Greek Novel," in Swain 1999a: 3-35.

Tilg, S. 2010. Churiton of Aphrodisias and the Invention of the Greek Love Novel. Oxford.

Trenkner, S. 1958. The Greek Novella in the Classical Period. Cambridge.

Van Steen, G. 1998. "Destined to Be? Tyche in Chariton's Chaereas and Callirhoe and in the Byzantine Romance of Kallimachos and Chrysorroi," AntCl 67: 203-211.

Weichberger, K. 1898. "Die Urquelle von Shakespeare's 'Much Ado About Nothing'," Jabrbuch der deutschen Shakespeare-Gesellschaft 34: 339-345.

Whitmarsh, T. 2005. "The Greek Novel: Titles and Genre," AJP 126: 587-611.

Willink, C. W. 1968. "Some Problems of Text and Interpretation in the Hippolytus," CQ N.S. $18: 11-43$. 
CHAEREAS, HIPPOLYIUS, TIIESEUS: TRAGIC ECHOHS, TRAGIC PO'TENTIALIN CHARITON

\section{J. H. D. SCOURFIELD}

This article argues for the presence of previously unrecognized intertextual connections between Euripides' Hippolytus and two scenes in Chariton's Chateras and Callirboe, one of them of central importance to the action of the novel; and then considers the consequences of this identification for our reading of Chariton's work.

Cet article démontre la présence de rapports intertextuels qu'on n'avait pas ce jour identifies entre l'Hippolyte d'Euripide et deux scénes du roman de Chariton, Chivias at Callirhoi'; l'une de ces scenes est d'importance capitale pour l'action du roman. L'article s'intéresse ensuite aux conséquences de ces liens sur notre lecture de l'eeuvre de Chariton.

\section{IPSA IMWVRT: WOMEN'S WORDS IN ROMAN LOVE ELECYY}

\section{SHARON I. JAMES}

The speech of women in Roman love elegy, represented in oratio recta, sratio obligua, and summarized or inferable spech, does not characterize any putlla. Outside of Propertius Book 4, all female elegiac specech is generic, designed to reflect what the male lovers want and to manipulate them.

Lat parole des femmes dans l'élégie anourcuse romaine, mise en scne en discours direct, discours indirect, résumcéc ou insinuée, ne représente aucune purlla. À l'exception du live IV de P’roperce, tous les discours clégiagues féminins sont génériques, destinés ì reféter ic que l'amant recherche et a les manipuler.

\section{PASSÉISMLET MODERNISME AU DÉBUT DU SECOND SIECLE:}

I.J CAS DI: PLINE LE JEUNE

\section{Nicole Míthy}

Attachment to the past and modernism are equally present in Pliny the Younger's thought. The former is based on traditional moral criteria, the latter on newer, intellectual and spiritual criteria. This integration in a system of values allows the author to reconcike both attitudes and to transecond them.

Passéisme et modernisme sont également présents dans la pensée de Pline le Jeune. Le premier se fonde sur des critères moraux, traditionnels, le second sur des critères intellectucls et spirituels, plus nouveaux. Cette intégration dans un systeme de valeurs permet de concilier les deux attitudes et de les dépasser. 